\title{
Flexible foraging tactics by a large opportunistic seabird preying on forage- and large pelagic fishes
}

\author{
W. A. Montevecchi ${ }^{1, *}$, S. Benvenuti ${ }^{2}$, S. Garthe ${ }^{3}$, G. K. Davoren $^{4}$, D. Fifield ${ }^{1}$ \\ ${ }^{1}$ Cognitive and Behavioural Ecology Program, Memorial University, St. John's, Newfoundland and Labrador A1B 3X9, Canada \\ ${ }^{2}$ Department of Ethology, Ecology and Evolution, University of Pisa, Via Volta 6, 56126 Pisa, Italy \\ ${ }^{3}$ Research and Technology Centre (FTZ), University of Kiel, Hafentörn 1, 25761 Büsum, Germany \\ ${ }^{4}$ Department of Zoology, University of Manitoba, Winnipeg, Manitoba R3T 2N2, Canada
}

\begin{abstract}
Generalist and opportunistic marine predators use flexible foraging behaviour to exploit prey bases that change in diversity and spatial and temporal distributions. Behavioural flexibility is constrained by characteristics such as individual cognitive and physical capabilities, age, reproductive condition and central place foraging. To assess flexibility in the foraging tactics of a marine bird, we investigated the diets and foraging behaviour of the largest seabird predator in the North Atlantic Ocean. Northern gannets Sula bassana exploit a broad spectrum of pelagic prey that range in mass by more than 2 orders of magnitude. We investigated their foraging activity at their largest offshore colony in the western Atlantic Ocean during 1998 to 2002, when they preyed primarily on shoals of spawning and post-spawning capelin Mallotus villosus, a small forage fish $(\sim 15 \mathrm{~g})$, and also on a much larger pelagic fish, post-smolt Atlantic salmon Salmo salar ( 200 g). Inter-annual dietary variation is associated with gannet and prey fish distributions. Landings of capelin at the colony by gannets were correlated with returns of larger foraging flocks from inshore, whereas landings of Atlantic salmon were associated with smaller flocks returning from offshore. Maximum foraging trip distances ranged from 20 to $200 \mathrm{~km}$ and averaged $57 \pm 12$ (SE) km, consistent with distances to inshore capelin aggregations. When capelin abundance was low (in 2002), more gannets foraged offshore, preyed on large pelagic fishes (mostly Atlantic salmon) and exhibited the greatest dietary diversity. Though the outbound portions of foraging trips were more sinuous than inbound routes, individual gannets exhibited general fidelity to foraging sites. These large avian predators used flexible foraging tactics to adjust to changing prey conditions and generate longer-term strategies to take advantage of diverse trophic interactions over a range of ocean ecosystems.
\end{abstract}

KEY WORDS: Foraging tactics · Seabirds · Forage fishes · Diets · Capelin · Gannet · Atlantic salmon · Ecosystem

Resale or republication not permitted without written consent of the publisher

\section{INTRODUCTION}

Predators behave opportunistically to take advantage of changing prey and environmental conditions. Many marine apex predators exhibit flexible foraging behaviour to exploit shifting prey diversity and their changing spatial and temporal distributions (Croxall 1987, Bowen et al. 2006, Watanuki et al. 2008). This behavioural flexibility is mediated by the decision making of individual predators each being constrained by its own cognitive and physical capabilities. Individ- uals bring both transient and steady-state behaviour to navigate their daily lives in dynamic marine environments (Ollason et al. 2006). Breeding seabirds are further constrained by working to meet the increasing energy demands of offspring while foraging from a fixed colony site (Orians \& Pearson 1979)

Among large seabird predators, gannets employ flexible tactics to capture a variety of ephemeral pelagic prey that can vary in mass from tens to many hundreds of grams (Montevecchi \& Berruti 1991, Bunce 2000, Hamer et al. 2001). They also scavenge 
discards and offal from fishing vessels (Burger \& Cooper 1984, Garthe et al.1996). The largest gannet and the largest North Atlantic seabird, the northern gannet Sula bassana delivers loads of from one to tens of prey items (numbers inversely related to prey mass that range from $<10$ to $>500 \mathrm{~g}$ ) to rapidly growing, lipid-loading chicks during a $13 \mathrm{wk}$ nestling period (Montevecchi et al. 1984). Chicks are fed primarily large oily pelagic fishes (e.g. Atlantic mackerel Scomber scombrus, Atlantic herring Clupea harengus) and at times small forage fishes (e.g. capelin Mallotus villosus, sand lance Ammodytes spp.; Nelson 1980, Montevecchi \& Myers 1995, Garthe et al. 2007b).

Associated with a centennially anomalous cold-water perturbation in the northwest Atlantic Ocean during 1991 (Drinkwater 1996), northern gannets switched from preying on large migratory, warm-water species (Atlantic mackerel, Atlantic saury Scomberesox saurus, short-finned squid Illex illecebrosus; their dominant prey during the late 1970s and 1980s) to cold-water fishes, primarily capelin, for longer than a decade (Montevecchi 2007). Throughout this period, gannets have successfully provisioned offspring, and their populations in the northwest Atlantic Ocean have grown substantially (Chardine 2000).

In this paper, we integrate different levels of dietary and behavioural analyses to highlight the foraging tactics of northern gannets when preying on small forage fishes (capelin) and large pelagic fishes (e.g. Atlantic salmon Salmo salar) during 1998 to 2002. Inter-annual variation in diets is compared with concurrent avian and capelin distributions and densities obtained from vessel surveys during 1998 to 2002. Off the northeast Newfoundland coast, Canada, capelin shoals exploited by avian and mammalian predators often persist in fixed locations (Davoren et al. 2003b), and we assessed the gannets' fidelity to foraging areas (e.g. Hamer et al. 2001, Watanuki et al. 2003) by comparing the directions and distances of successive trips by the same individuals equipped with compass loggers. The returning directions and sizes of foraging flocks were related to landings of capelin and of large pelagic fishes, mostly Atlantic salmon, and foraging trip patterning was explored by comparing the fractal dimensions of outbound and inbound routes. Because seabirds often use different foraging strategies when provisioning themselves versus when gathering food for offspring (Weimerskirch et al. 1994, Davoren \& Burger 1999), we compared the distances from the colony of terminal diving bouts on a foraging trip (chick provisioning dives) with the distances of previous diving bouts (presumably those for self-provisioning). We use this information to assess the flexible foraging tactics used by the largest seabird predator in the North Atlantic Ocean.

\section{MATERIALS AND METHODS}

Study site and period. Research was carried out on Funk Island $\left(49^{\circ} 45^{\prime} \mathrm{N}, 53^{\circ} 11^{\prime} \mathrm{W}\right)$, a small $(800 \times 400 \mathrm{~m})$ flat granite rock in the northwest Atlantic Ocean (Montevecchi \& Tuck 1987), about $50 \mathrm{~km}$ off the northeast coast of Newfoundland (Fig. 1). The island has an estimated population of 9800 pairs of northern gannets (Chardine 2000) and is the 4th largest and most oceanic of the 6 gannet colonies in North America. Researchers were on the island from 4 to 17 August 1998, 26 July to 5 August 1999, 5 to 13 August 2000, 30 July to 7 August 2001 and 6 to 13 August 2002.

Diet sampling. Food samples were obtained by approaching roosting gannets that often regurgitated food as they moved away from researchers (Montevecchi \& Myers 1995). Samples were also obtained from birds captured for data logger attachments and removals and from discarded regurgitations and scraps in the colony. While there are likely differences between samples collected in roosts and in the colony, samples from these sources are comparable (W. A. Montevecchi unpubl. data), and we opted to minimize disturbance to breeders by collecting regurgitations at roosts well outside the colony. Regurgitated prey items were identified to species level, fresh fish samples were measured for total length and very fresh fish were weighed with spring scales. Prey landings are presented as percentages of total regurgitations during each year.

Scans of $360^{\circ}$ for flocks returning to colony. The numbers of gannets in incoming flocks were recorded by means of scans at various times of day. Counts were recorded within each $45^{\circ}$ sector of a $360^{\circ}$ scan performed from the island's highest point near the northeast end with compass-directional binoculars that were held with the horizon at mid-diameter as the observer slowly scanned the sector for $1 \mathrm{~min}$. Three full rotations (24 min) comprised a scan session. Wind speed and direction were recorded with a hand-held anemometer and the directional binoculars at the outset of scans and, if conditions changed, also at the end. Two or three observers counted each year, usually working in pairs with one person counting and the other recording; counts were recorded on a portable tape recorder when a single observer counted. Because observers worked in multiple years most often in pairs of the same observers, and because data were analyzed in $90^{\circ}$ quadrants, influences of individual differences were minimized. Frequencies of returning foragers within $90^{\circ}$ quadrants were compared on daily and annual bases with chi-square tests, and numbers were plotted as percentages of total counts. Comparisons of the percentages of gannets returning from inshore $\left(135\right.$ to $\left.315^{\circ}\right)$ and offshore (315 to $\left.135^{\circ}\right)$ directions 


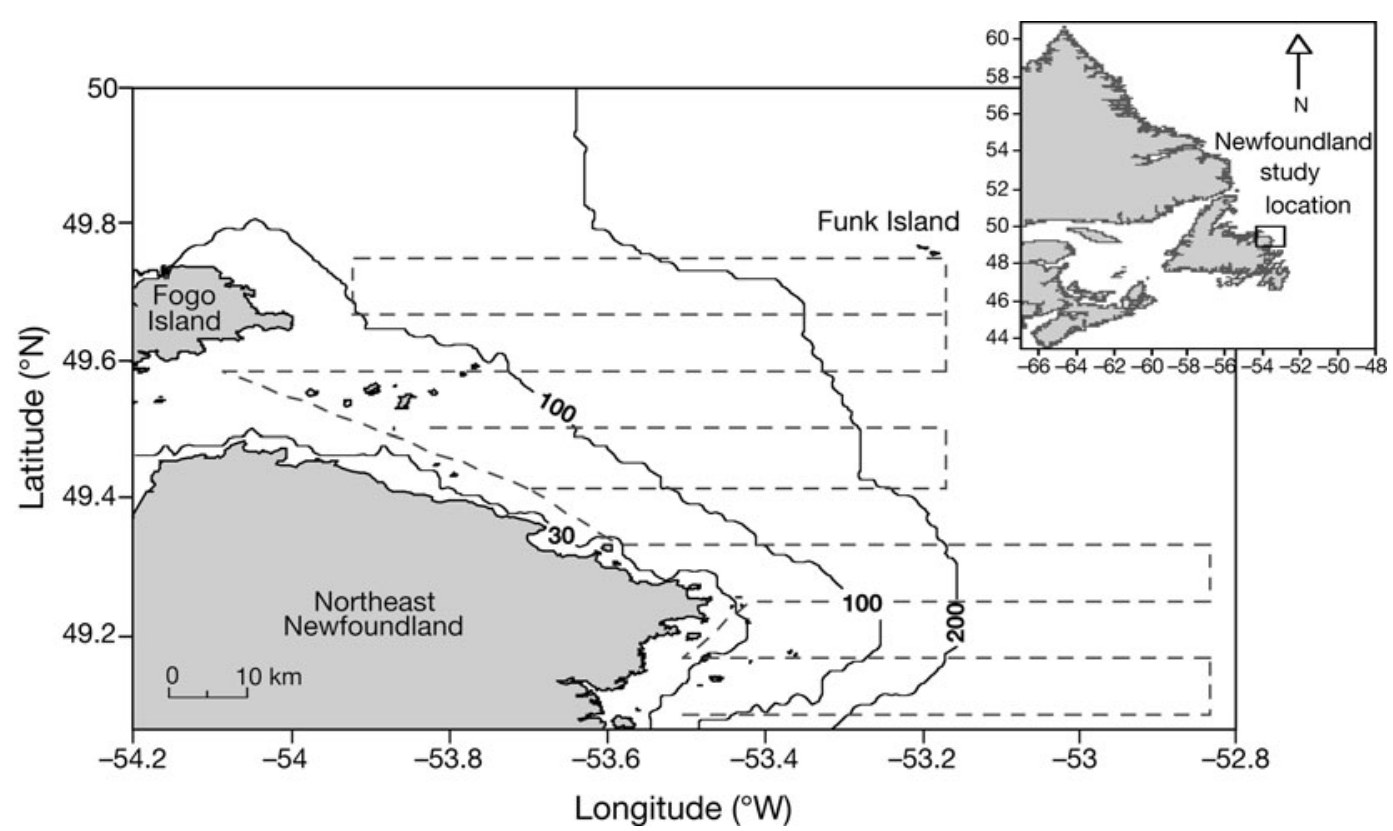

Fig. 1. Study area showing Funk Island and vessel survey routes off the northeast coast of Newfoundland

were correlated with the numbers of regurgitations of the 4 most common prey (capelin, Atlantic salmon, Atlantic saury, Atlantic herring) landed in the colony on the same day. The average sizes of flocks returning from inshore and offshore were compared with 1-way ANOVA.

Vessel surveys and spatial distribution calculations. A mesoscale (1 to $800 \mathrm{~km}$ ) survey aboard the $23 \mathrm{~m}$ Canadian Coast Guard research vessel 'Shamook' was conducted over $5 \mathrm{~d}$ within avian foraging ranges and prime capelin spawning and staging areas to the south and west of Funk Island during July and August 2000 to 2002 (Fig. 1). Nine east-west cross-shelf transects $9 \mathrm{~km}$ apart on north-south axis were run during the $12 \mathrm{~h} \mathrm{~d}^{-1}$ that the 'Shamook' operated. Surveys were periodically interrupted to identify the species composition of acoustic signals using a modified shrimp trawl. The majority of fish sampled by mass were capelin in each year (2000: 96\%; 2001: $71 \%$; 2002: $55 \%$ ).

During transects, vessel speed (11 to $16 \mathrm{~km} \mathrm{~h}^{-1}$ ) was held constant and signals of prey species were recorded continuously using 2 hydroacoustic systems. For the 2000 survey, a EQ100 system (Simrad) was operated through a hull-mounted single $38 \mathrm{kHz}$ beam transducer that operated at 1 ping s ${ }^{-1}$ over a range of $250 \mathrm{~m}$ with a bandwidth of 0.4 to $0.6 \mathrm{~ms}$. The transducer was at a depth of $3 \mathrm{~m}$ and acoustic signals were reliable at $8 \mathrm{~m}$ and deeper. The sample depth of the acoustic system (8 to $250 \mathrm{~m}$ ) and vessel speed (14 to $16 \mathrm{~km} \mathrm{~h}^{-1}$ ) were held constant throughout all surveys. Echograms were continuously printed and the relative abundance of fish was quantified by estimating the percent cover of the prey image in each $250 \times 10 \mathrm{~m}$ vertical bin (Piatt 1990). An index of percent cover of prey in each bin was estimated from 0 (no prey) to 9 (near saturation). Values were squared before analysis ( 0 to 81) to account for the non-linear change in sounder intensity relative to fish school density (Piatt 1990), giving a relative measure of acoustic prey abundance.

During 2001 and 2002, a DT 6000 hydroacoustic system (BioSonics) operated through a $38 \mathrm{kHz}$ split-beam transducer in a towed body. The transducer had a 2way beam angle of $22.671 \mathrm{~dB}$ and the echo sounder was operated at 1 ping s$^{-1}$, a bandwidth of $5.1 \mathrm{kHz}$ and a pulse duration of $0.4 \mathrm{~ms}$. The transducer was at a depth of $5 \mathrm{~m}$ and the upper resolution of the acoustic signals (8 to $10 \mathrm{~m}$ ) was well within the diving range of northern gannets to $20 \mathrm{~m}$ (Garthe et al. 2000). Vessel speed was maintained between 11 to $14 \mathrm{~km} \mathrm{~h}^{-1}$. Raw high resolution acoustic data (volume backscattering coefficients, $S_{V}$ ) were recorded continuously and used to derive capelin biomass estimates $\left(\mathrm{g} \mathrm{m} \mathrm{m}^{-2}\right.$; see Davoren et al. 2006). Variability in the quality of hydroacoustic systems used and data processing techniques precluded comparing capelin abundance among years, but allowed inter-annual comparisons of distributional patterns.

During acoustic transects, seabirds were counted continuously by a single observer in a $90^{\circ}$ arc out to $300 \mathrm{~m}$ from the bow to the port side of the ship using standard strip methods (Tasker et al. 1984). Counts with behavioural descriptions (on water, flying, feeding) were entered into a laptop computer with counting software (D. Senciall, Birds \& Beasty Counter, Fish- 
eries and Oceans Canada, v. 1.0 [1998]) connected to the vessel's navigational system. A latitude-longitude position was appended to each sighting.

Capture of birds. Adult gannets with 4 to 6 wk old chicks in their nests were captured with a telescoping noose pole from a small portable blind to minimize disturbance to neighbouring birds. We avoided capturing pairs with younger poikilothermic chicks as this was more disturbing to parents, and because parents with older chick had greater energetic demands. Pairs on the colony's periphery were used to avoid disruption to the interior colony; to reduce possible sampling bias in potential differences between peripheral and interior nesting pairs, we captured birds in the 3rd or 4th rows from the colony edge. Breeding success was high at the sites where we worked (W. A. Montevecchi \& S. Garthe pers. obs.). Birds were captured, marked on the head and neck with colored markers for identification from a distance, equipped and banded with US Fish and Wildlife Service (USFWS) bands issued by the Canadian Wildlife Service usually within 5 to $10 \mathrm{~min}$. We held the necessary university, provincial and federal permits, and birds were treated in accordance with the guidelines of the Canadian Council on Animal Care.

Data loggers. Four types of data loggers were used on 24 breeding adult gannets for a total of 49 foraging trips. Durations of attachments varied from 27 to $75 \mathrm{~h}$. We attached LTD (light-temperature-depth)-100 tags (Lotek Marine Technologies) to 7 gannets that made 9 foraging trips in 1999. Dall'Antonia (DA) activity-depth recorders were deployed on 7 gannets that completed 16 foraging trips in 2001, DA compass loggers were attached to 7 gannets that completed 14 foraging trips in 2002, and compass Tlog devices (65 mm length, $16 \mathrm{~mm}$ diameter, 14.5 g, 2 MB memory; Earth \& Oceans) with horizontal direction recorders were also used to track 10 successive foraging flight paths of 2 gannets in 2003 and 1 in 2004. The data recording intervals set on each bird-borne device (below) allowed continuous recording for up to 3 to $4 \mathrm{~d}$, and the weight of each device weighed $\leq \sim 1 \%$ of a gannet's body mass. With the exception of the LTD-100 tags (see 'LTD loggers'), all loggers were attached with tesa tape to feathers on the lower back about $5 \mathrm{~cm}$ above the uropygeal gland or atop 4 central tail feathers. When an equipped gannet was recaptured, devices were removed quickly, and data were downloaded into a laptop computer.

LTD loggers: LTD-100 tags $(57 \mathrm{~mm}$ length, $18 \mathrm{~mm}$ diameter, $16 \mathrm{~g}$, $1 \mathrm{MB}$ memory) were attached with tesa tape to 2 plastic bands on one leg. Activity was inferred from thermal fluctuation records taken every $30 \mathrm{~s}$ (following Wilson et al. 1995, Garthe et al. 1999); dive depth data are reported elsewhere (Garthe et al. 2000, 2003). When temperature indicated sea surface temperature (SST) and remained constant, the bird was considered to be swimming or resting on the water with the logger submerged. When temperature varied slightly within the range of recorded air temperature (some degrees higher than SST), the bird was considered to be flying. When the temperature varied in higher ranges (as the logger was warmed by the bird's and chick's body heat and often solar and terrestrial radiation) and with other diurnal thermal rhythms, the bird was considered to be in the colony (i.e. at the nest most of the time). These occurrences were validated by observations using a spotting scope from outside the colony to check when marked birds carrying loggers were present at nest sites (Garthe et al. 2003).

Dall' Antonia activity-depth loggers: Dall' Antonia (DA) devices ( $80 \mathrm{~mm}$ length, 22 to $31 \mathrm{~mm}$ width, 13 to $18.5 \mathrm{~mm}$ height, $28 \mathrm{~g}, 128 \mathrm{kB}$ memory) recorded activity (from a motion sensor) every $6 \mathrm{~s}$ and depth (from a pressure sensor) every $4 \mathrm{~s}$ (Dall'Antonia et al. 1993, Benvenuti et al. 1998). In previous research (e.g. Garthe et al. 2000, 2007a), we demonstrated that U-shaped dives for capelin and V-shaped dives for large pelagic fishes like post-smolt Atlantic salmon are typically in excess of $4 \mathrm{~s}$, and we are confident that we recorded the foraging dives by the gannets in our study. The activity sensor (a $5 \mathrm{~mm}$ diameter modified microphone membrane) was activated by flight signals produced by accelerations and/or body vibrations caused by wing beats. During diving, signals are produced by wing and/or foot propulsions. Flight activity was identified on graphs as regular high-level deflections, easily distinguishable from the low frequency signals produced when the bird is on the sea surface and from weak irregular or absent signals when the bird is at the nest. Devices were attached either to feathers on the lower back about $5 \mathrm{~cm}$ above the uropygial gland or the 4 central tail feathers with tesa tape.

Compass loggers: DA compass loggers $(93 \mathrm{~mm}$ length, 22 to $33 \mathrm{~mm}$ width, 15 to $20 \mathrm{~mm}$ height, $33 \mathrm{~g}$, $128 \mathrm{kB}$ memory) with direction recorders, flight and pressure sensors and one with a flight recorder but no pressure sensor were used to track flight directions and activities (Benvenuti et al. 1998, 2001). Intervals between successive recordings were 6 to $8 \mathrm{~s}$ for both the compass logger and flight sensor and $4 \mathrm{~s}$ for the pressure sensor. Used in conjunction with satellite tags, these loggers indicated similar general foraging areas (Falk et al. 2001). Compass Tlog devices (65 mm length, $16 \mathrm{~mm}$ diameter, $14.5 \mathrm{~g}, 2 \mathrm{MB}$ memory) with horizontal direction recorders were also used to track foraging routes. Intervals between successive directional records were $6 \mathrm{~s}$.

Foraging routes, ranges and diving activity. Twenty-four compass routes from 10 parental gannets were plotted; 1 of these birds had 4 consecutive foraging routes recorded, 3 had 3, 5 had 2, and 1 had 1 route 
recorded. Foraging routes and ranges were reconstructed by multiplying an estimated average flight speed of $14.9 \mathrm{~m} \mathrm{~s}^{-1}$ (54 $\mathrm{km} \mathrm{h}^{-1}$; Pennycuick 1997) by the summed flight time along outbound and inbound foraging routes, time on water, a corrected magnetic declination $\left(-28^{\circ}\right)$ and wind influences (wind speeds and directions were recorded at the colony ['scans of $360^{\circ}$ for flocks returning to colony'] and also obtained from the Environment Canada weather station at Pool's Island near the mouth of Bonavista Bay and within the gannets' foraging range). Potential sources of error include imperfect alignment of a device with a gannet's body axis, drift when birds are on water and variable flight speeds in different wind conditions (Grémillet et al. 2004, D. Fifield \& W. A. Montevecchi unpubl. data). For the 7 gannets equipped in 2002, we estimated distances to all diving bouts (groups of dives, excluding those shallower than $1 \mathrm{~m}$, separated by long intervals of flying or swimming) and from the last dives of a foraging trip to the colony. Points of maximum trip distance were mapped for all 10 compass-equipped birds by extrapolating distances and directions from Funk Island on a 1:250 000 map of the northeast Newfoundland coast.

Scanned images of foraging trip routes during 2002 printed on $27.9 \times 43.2 \mathrm{~cm}$ paper were subjected to boxcounting fractal analysis using the HarFa Harmonic and Fractal Image Analyzer (available at: www.fch. vutbr.cz/lectures/imagessci/download/harfasp.html). Fractal dimensions of the (1) entire route, (2) outbound route to the most distant point, (3) outbound route to the last or terminal dive, (4) inbound route from the most distant point and (5) inbound route from the last or terminal dive. Fractal dimensions of (2) versus (4) and of (3) versus (5) were compared with $t$-tests for related samples and with binomial tests of differences (Siegel 1957). We describe the number and temporal and spatial patterning of diving bouts performed throughout trips; depth profiles of different diving patterns are reported by Garthe et al. (2000). We also assessed the consistency of foraging route directions on successive trips by 10 individual gannets.

\section{RESULTS}

\section{Prey landings}

Capelin comprised $77 \%$ of the prey loads returned to the colony, ranging from 51 to $100 \%$ on a per annum bases from 1998 to 2002 (Table 1). Atlantic salmon was the next most common prey with high annual variation ranging from 0 to $34 \%$ of landings. Atlantic saury, Atlantic herring and Atlantic mackerel made up relatively minor dietary components. During 1998 to 2000, capelin comprised more than $80 \%$ of prey landings, though the situation was somewhat different in 2001 and very different in 2002, when Atlantic salmon made up significant dietary components and when dietary diversity was greatest (Table 1). Northern gannet landings of capelin contained 6 to 20 fish compared with landings of salmon that contained 1 to 3 much larger fish.

\section{Directions and sizes of returning flocks and prey landings at colony}

The flight directions of incoming gannets are shown in Fig. 2. In all years, most birds returned to the colony from inshore foraging sites southwest of the island, except during 2002 when most returned from offshore sites north of the colony $\left(\chi^{2}=902.7, \mathrm{df}=12, \mathrm{p}<0.001\right)$.

Comparisons of the directions of returning birds and proportions of prey species landed at the colony revealed significant relationships between inshore returns and landings of capelin $(y=0.49 x+38.5, \mathrm{n}=$ $12, \mathrm{R}^{2}=0.33, \mathrm{p}=0.049$ ) and between offshore foraging and landings of Atlantic salmon $(y=1.15 x+19.1, \mathrm{n}=$ 12, $\mathrm{R}^{2}=0.60, \mathrm{p}=0.003$; Fig. 3). No relationships for other common prey (Atlantic herring, Atlantic saury) were detected $(p>0.05)$. The sizes of flocks returning from inshore were significantly larger than those returning from offshore in each year and in all years combined (Fig. 4). Flock sizes were lowest in the year 2002 when capelin was least abundant.

Table 1. Sula bassana. Percentages of each prey species in regurgitations (with numbers in parentheses) by northern gannets on Funk Island, 1998 to 2002

\begin{tabular}{|c|c|c|c|c|c|c|}
\hline Prey & 1998 & 1999 & 2000 & 2001 & 2002 & 1998-2002 combined \\
\hline Capelin & $84(384)$ & $87(86)$ & $100(183)$ & $72(153)$ & $51(145)$ & 77 (951) \\
\hline Atlantic salmon & $1(5)$ & 0 & 0 & $25(54)$ & $34(95)$ & $12(154)$ \\
\hline Atlantic saury & $12(56)$ & $10(10)$ & 0 & $1(3)$ & $3(9)$ & $6(78)$ \\
\hline Atlantic herring & $3(15)$ & $3(3)$ & 0 & $2(4)$ & $3(8)$ & $2(30)$ \\
\hline Atlantic mackerel & 0 & 0 & 0 & 0 & $9(25)$ & $2(25)$ \\
\hline Totals & $100(460)$ & $100(99)$ & $100(183)$ & $100(214)$ & $100(282)$ & $99(1238)$ \\
\hline
\end{tabular}



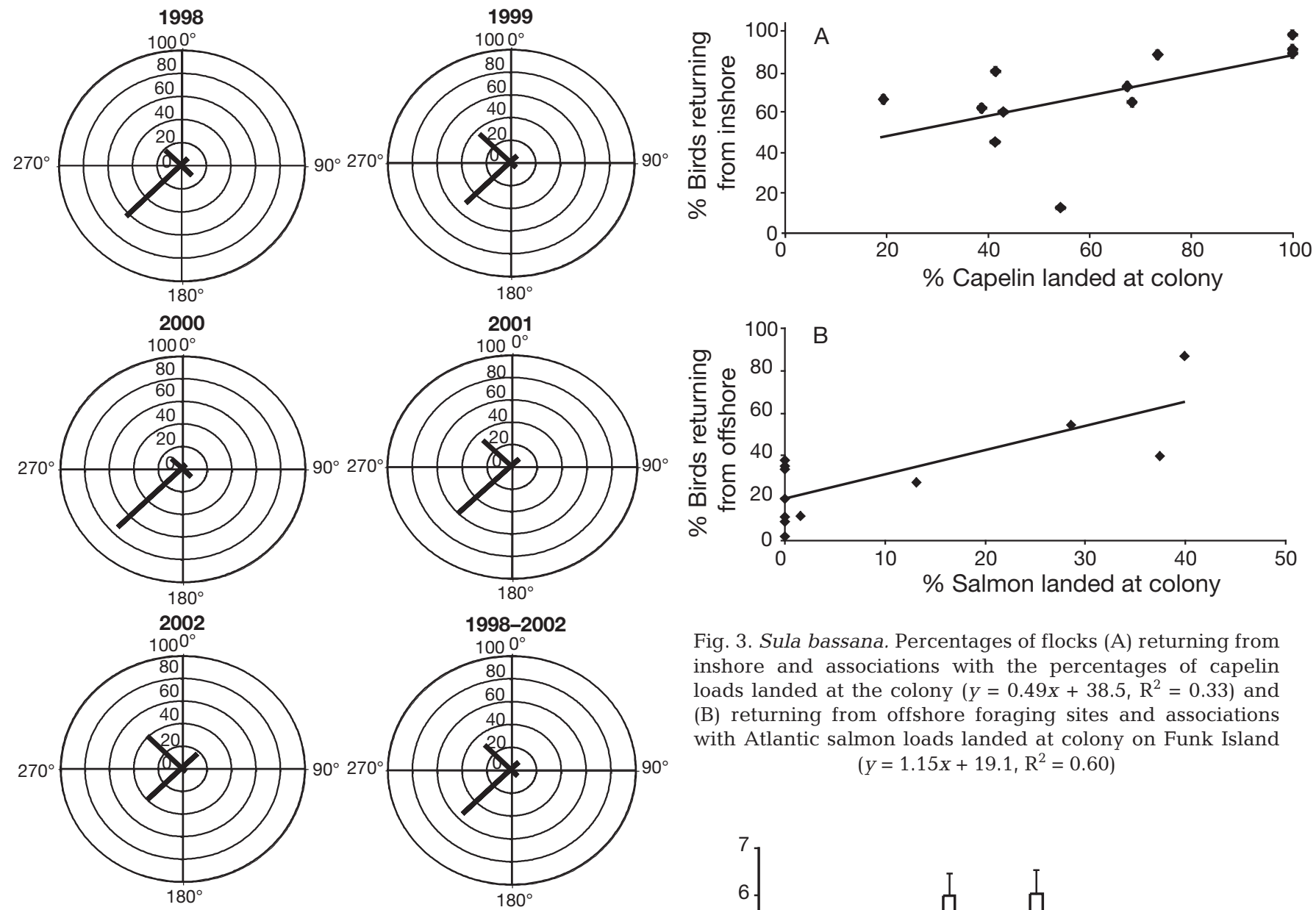

Fig. 3. Sula bassana. Percentages of flocks (A) returning from inshore and associations with the percentages of capelin loads landed at the colony $\left(y=0.49 x+38.5, \mathrm{R}^{2}=0.33\right)$ and (B) returning from offshore foraging sites and associations with Atlantic salmon loads landed at colony on Funk Island $\left(y=1.15 x+19.1, R^{2}=0.60\right)$

Fig. 2. Sula bassana. Polar plots of directions (in $90^{\circ}$ sectors) of flocks of foraging northern gannets returning to the colony on Funk Island, 1998 to 2002 and all years combined

\section{Distributions of gannets along vessel transects}

Observers on research vessels noted consistent general travel routes of northern gannets to and from Funk Island from areas southwest of the colony. Capelin abundance was substantially lower in 2002, showing a 7-fold decrease from 2001 (Fig. 5, Table 2). The number of gannets per $\mathrm{km}$ along the survey route was also significantly lower during 2002, being less than onethird of those recorded in 2000 and 2001 (Table 2). Interestingly, 2002 was the only year when more foragers returned from offshore areas north of the island (Fig. 2) and the year when most Atlantic salmon were landed at the colony (Table 1).

\section{Foraging trips, range and area}

Foraging trips consisted of alternated series of flights and stops of variable durations that include dives and

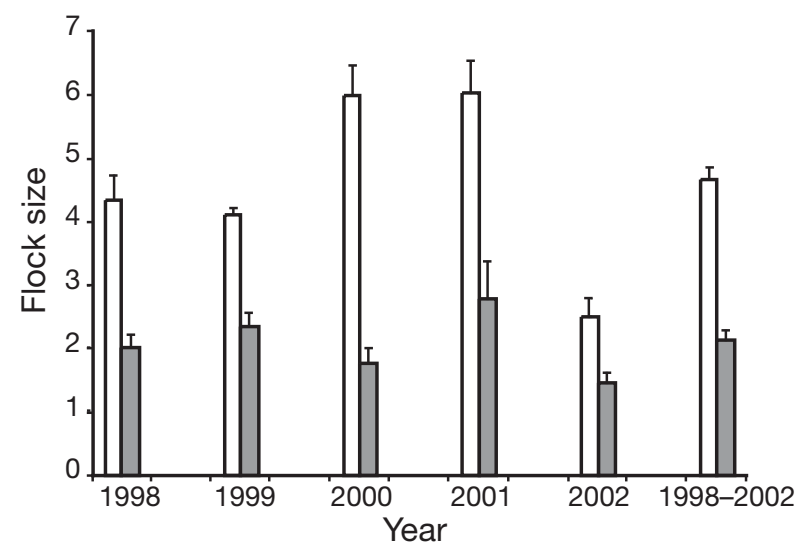

Fig. 4. Sula bassana. Average sizes of flocks returning from inshore (white bars) and offshore (grey bars) foraging areas, 1998 to 2002

sitting on the water, with 1 or 2 longer flights performed most often at the beginning and end of the trips. Most diving activity occurred during the middle segments of foraging flights $\left(\chi^{2}=48.26\right.$, df $=4, p<$ 0.001; Fig. 6), indicating that there was little foraging activity in close proximity to the colony. Colony departures occurred between sunrise and sunset with no apparent diurnal concentration (see also Garthe et al. 2003). Foraging trip durations of birds with compass 

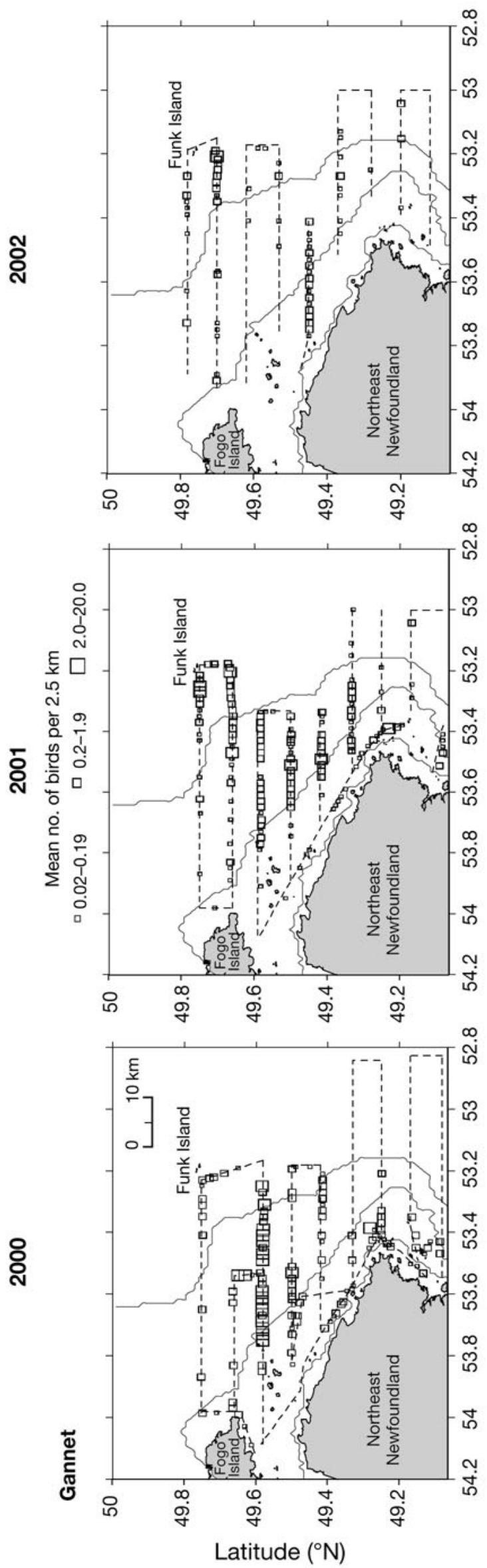

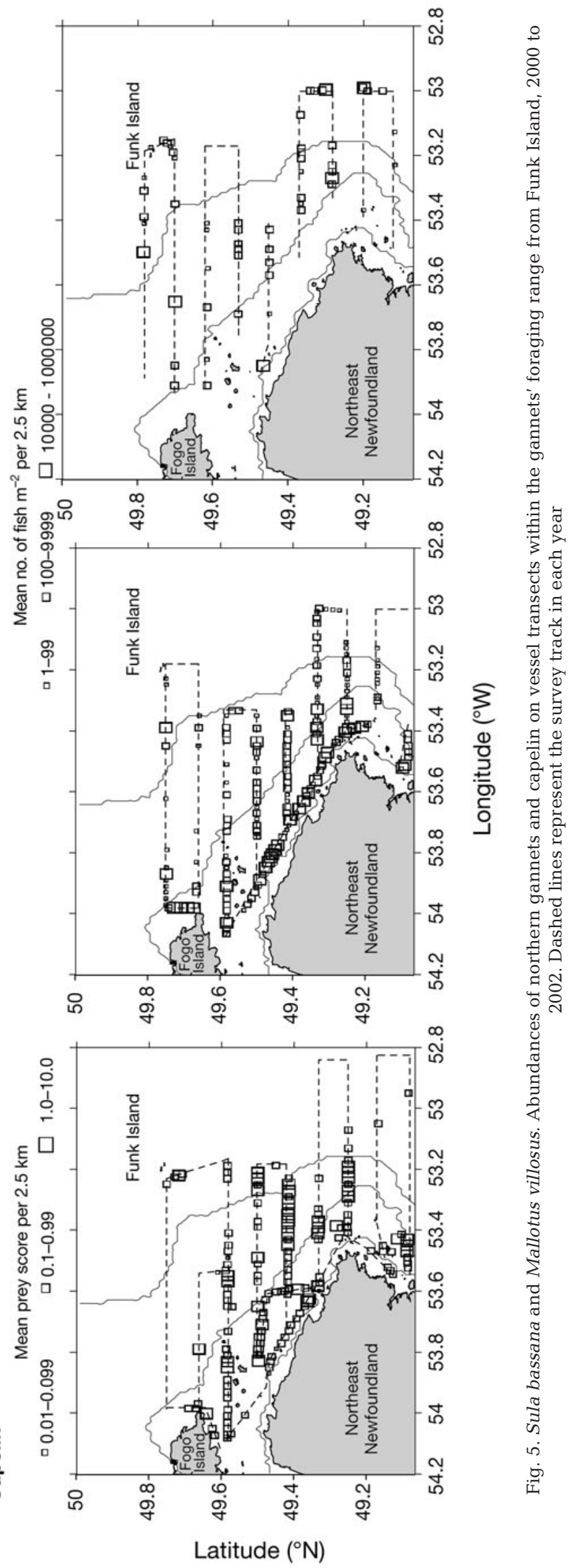


Table 2. Sula bassana and Mallotus villosus. Number, density and biomass estimates of northern gannets and capelin within the survey area in 2000, 2001 and 2002. A different hydroacoustic technique was used in 2000, so capelin biomass could not be quantified and compared with 2001 and 2002

\begin{tabular}{|lccc|}
\hline & 2000 & 2001 & 2002 \\
\hline No. of gannets ${ }^{\mathrm{a}}$ & 685 & 962 & 220 \\
\% Flying & 65 & 70 & 94 \\
\% Plunge diving & 1 & 1 & 0 \\
\% Sitting on the water & 34 & 29 & 6 \\
Mean \pm SE no. of gannets per $\mathrm{km}^{\mathrm{b}}$ & $0.13 \pm 0.03$ & $0.10 \pm 0.01$ & $0.03 \pm 0.01$ \\
No. of capelin shoals & 204 & 358 & 79 \\
Mean capelin length (mm) & 159.5 & 151.2 & 151.4 \\
Mean capelin mass $(\mathrm{g})$ & 18.7 & 17.7 & 19.7 \\
Mean capelin density (fish $\left.\mathrm{m}^{-2}\right)$ & - & 53.2 & 7.3 \\
Total areas of the survey $\left(\times 10^{6} \mathrm{~m}^{2}\right)$ & 5487 & 5487 & 5487 \\
Estimated number of capelin $\left(\times 10^{6}\right)$ & - & 291942 & 39821 \\
Estimated biomass of capelin $(\mathrm{t})$ & - & 5171 & 785 \\
Survey length $(\mathrm{km})$ & 610 & 431 & 373 \\
${ }^{\mathrm{a}}$ Chi-square test: $\chi^{2}=68.74, \mathrm{df}=4, \mathrm{p}<0.0001$ & & \\
${ }^{\mathrm{b}} \mathrm{F}=5.963, \mathrm{df}=1020, \mathrm{p}=0.003$ & & & \\
\hline
\end{tabular}

loggers were variable, ranging from 3.3 to $26.2 \mathrm{~h}$, with mean $( \pm \mathrm{SD})$ and median durations of $9.5 \pm 5.8$ and $8 \mathrm{~h}$, respectively (Table 3 ). Birds that departed in the morning usually returned before sunset, whereas those that left in the afternoon usually remained at sea overnight and returned the next morning.

On foraging trips, gannets with compass loggers spent about half ( $49 \%$, range from 31 to $71 \%$ ) of the daylight time away flying. Birds remained on the water and did not fly after dark. Total flight durations ranged between 1.9 and $13.7 \mathrm{~h}$, with mean $( \pm \mathrm{SD})$ and median durations of $3.8 \pm 3.0$ and $2.9 \mathrm{~h}$, respectively. Time spent flying increased with trip duration $(\mathrm{r}=0.90, \mathrm{n}=$ $14, \mathrm{p}<0.001)$, indicating more travelling and potentially more searching on longer foraging trips. The more often birds dived the longer they rested on water after diving $(\mathrm{r}=0.82, \mathrm{n}=18, \mathrm{p}<0.001$ for first dive bouts; $r=0.53, \mathrm{n}=75, \mathrm{p}<0.001$ for all dive bouts).

Based on a flying speed of $54 \mathrm{~km} \mathrm{~h}^{-1}$ (Pennycuick $1997)$, values $( \pm$ SD) for maximum outbound distances

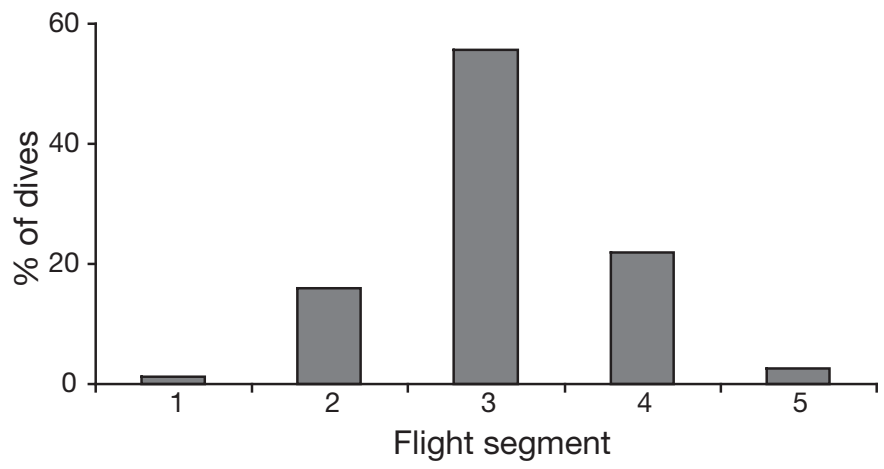

Fig. 6. Sula bassana. Percentages of dives during each $20 \%$ flight segment of foraging trips from the colony (foraging range) on individual trips during 2002 averaged $61 \pm 44 \mathrm{~km}(\mathrm{n}=14$ trips, median and mode $=50 \mathrm{~km}$ ) and ranged from 30 to $200 \mathrm{~km}$ (Table 4, Fig. 7). Estimated flight distances between the colony and the first feeding site ranged from 10 to $193 \mathrm{~km}$. Foraging ranges were shorter in 2003 and 2004 when capelin again predominated gannet landings (Montevecchi 2007) and averaged $41 \pm$ $21 \mathrm{~km}$ (n = 10 trips; Table 4).

The mean number of activity changes from swimming to flying and vice versa was significantly greater on outbound (5.3) than on inbound flights (2.8; $t=2.986, \mathrm{n}=24, \mathrm{p}=0.007)$. The mean $( \pm \mathrm{SD})$ fractal dimensions of outbound flights $(1.29 \pm 0.12)$ were not significantly different from those of inbound ones $(1.24 \pm 0.13 ; t=0.12, \mathrm{n}=14$, $\mathrm{p}>0.05)$ nor were the mean fractal dimensions of foraging routes out to $(1.26 \pm 0.14)$ and back from terminal dive bouts $(1.18 \pm 0.15 ; t=0.12, \mathrm{n}=14, \mathrm{p}>0.05)$. Yet, 11 of 14 outbound routes had higher fractal dimensions than did corresponding inbound routes on the same trips by the same individuals (binomial test, $\mathrm{p}=0.029$ ) and 10 of 12 routes to the terminal dive bout had higher fractal dimensions than did their corresponding inbound routes (binomial test, $\mathrm{p}=0.019$ ).

There was no significant difference in the average $( \pm \mathrm{SD})$ number of dives during the last or terminal diving bouts of a trip $(5.1 \pm 4.1$, range: 1 to 16$)$ compared with previous diving bouts on the same trip $(4.7 \pm 7.2$, range: 1 to $30 ; F=0.61$; df $=1,31 ; \mathrm{p}>0.05)$. Of 12 terminal diving bouts, 11 involved multiple dives com-

Table 3. Sula bassana. Durations (h) of compass logger attachments, foraging trips (and numbers of trips) and flight activity during each trip of 7 northern gannets rearing 4 to $6 \mathrm{wk}$ old nestlings on Funk Island during 2001

\begin{tabular}{|lccccccc|}
\hline Gannet: & 1 & 2 & 3 & 4 & 5 & 6 & 7 \\
\hline $\begin{array}{l}\text { No. of trips } \\
\text { Duration }\end{array}$ & 2 & 3 & 2 & 2 & 2 & 2 & 1 \\
Equipment & 29.3 & 51.1 & 44.0 & 44.0 & 49.9 & 40.2 & 51.5 \\
attachment & & & & & & & \\
$\quad$ Trip 1 & 5.8 & 14.4 & 9.1 & 3.3 & 12.1 & 5.4 & 5.7 \\
Trip 2 & 6.7 & 4.7 & 4.9 & 14.5 & 26.2 & 11.9 & \\
Trip 3 & & 8.0 & & & & & \\
Flight & & & & & & & \\
Trip 1 & 2.7 & 4.6 & 2.9 & 1.8 & 2.7 & 2.8 & 3.6 \\
Trip 2 & 2.7 & 2.9 & 1.9 & 5.1 & 13.7 & 3.2 & \\
Trip 3 & 2.5 & & & & & & \\
\hline
\end{tabular}


pared with 10 of 19 previous diving bouts on the same trip $\left(\chi^{2}=5.13, d f=1, p=0.024\right)$. On a foraging trip, the time spent resting on the water after terminal diving bouts (20.8 $\pm 23.0 \mathrm{~min})$ was about one-half of that after previous diving bouts $(36.8 \pm 31.5 \mathrm{~min})$ though owing to variability this tendency was not statistically significant $(t=0.157 ; \mathrm{df}=1,12 ; \mathrm{p}>0.05)$.

Individual gannets returned to the colony from all directions, ranging from 30 to $355^{\circ}$ (Table 4). Consis-

Table 4. Sula bassana. Foraging trip directions and maximum distances (ranges) during 1st, 2nd, 3rd and 4th foraging trips by northern gannets equipped with compass loggers

\begin{tabular}{|c|c|c|c|c|c|c|c|c|}
\hline \multirow{2}{*}{ Gannet no. } & \multicolumn{4}{|c|}{ Direction $\left({ }^{\circ}\right)$} & \multicolumn{4}{|c|}{ Max. distance $(\mathrm{km})$} \\
\hline & $1 \mathrm{st}$ & 2nd & 3rd & 4 th & $1 \mathrm{st}$ & 2nd & 3rd & 4th \\
\hline \multicolumn{9}{|l|}{2001} \\
\hline 1 & 200 & 190 & & & 50 & 50 & & \\
\hline 2 & 355 & 345 & 30 & & 70 & 60 & 60 & \\
\hline 3 & 205 & 190 & & & 40 & 30 & & \\
\hline 4 & 130 & 80 & & & 40 & 90 & & \\
\hline 5 & 205 & 340 & & & 30 & 200 & & \\
\hline 6 & 200 & 250 & & & 50 & & 50 & \\
\hline 7 & 40 & & & & 40 & & & \\
\hline \multicolumn{9}{|l|}{2003} \\
\hline 8 & 278 & 278 & 228 & & 63 & 47 & 25 & \\
\hline 9 & 173 & 222 & 199 & 185 & 67 & 12 & 46 & 53 \\
\hline \multicolumn{9}{|l|}{2004} \\
\hline 10 & 51 & 152 & 65 & & 62 & 16 & 19 & \\
\hline
\end{tabular}

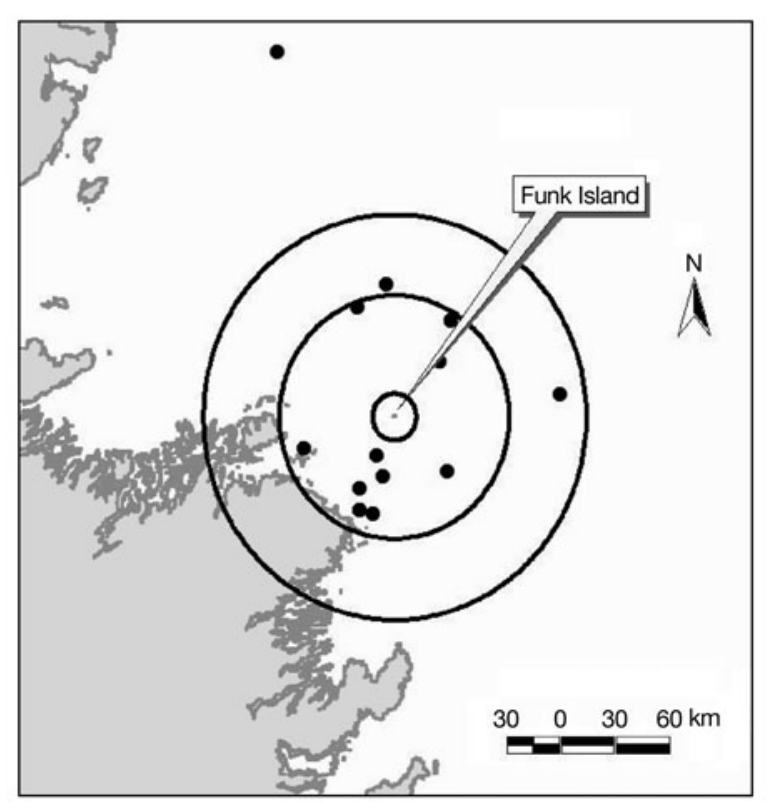

Fig. 7. Sula bassana. Maximum distances from the colony during foraging trips by parental northern gannets $(\bullet)$ and average foraging range estimates for first dives (inner circle), median (middle circle) and maximum (outer circle) for northern gannets nesting on Funk Island off the northeast Newfoundland coast tent with the scan data in 2002, mean $( \pm$ SD) and median return directions of foraging flocks were $187 \pm$ 100 and $200^{\circ}$, respectively. Six of seven successive trips were within $90^{\circ}$ of one another, and the average difference in flight direction between successive foraging trips by the same individual was $45 \pm 17^{\circ}$ (Table 4 ). Again in 2003 and 2004, mean and median return directions of foraging trips were from the south at $181 \pm 78$ and $192^{\circ}$. As well, 6 of 7 of foraging trips by 3 ind. tracked during 10 foraging trips were also within $90^{\circ}$ of one another, averaging $46 \pm 35^{\circ}$ directional differences between successive foraging trips (Table 4). Combing data for the 10 compass-equipped gannets, the average and median directions of returning foraging flocks were $191 \pm 92$ and $200^{\circ}$, respectively, and the overall mean angular deviation between 14 successive foraging trips by these individuals was $43 \pm 40^{\circ}$, with a median angular difference between successive trips of $34^{\circ}$.

\section{DISCUSSION}

\section{Responses of gannets to device attachments}

Birds were probably influenced by device attachments. Yet, as in our other studies that have employed some of the same attachments on northern gannets in this same colony, there was little evidence to indicate deleterious effects (Garthe et al. 2000, 2003, 2007a). Following attachments, birds returned quickly to nest sites, and parental behaviour, feeding and chick care and condition appeared normal. The foraging trip durations of equipped birds were not significantly different from those of their unequipped mates (S. Garthe unpubl.). Of 24 birds equipped with loggers, only 3 were not recaptured ( 2 of these were at sea when we had to depart the island due to bad weather), indicating that the stress related to capture, handling and attachments was surmountable. The other bird that we did not recapture had an approximately $8 \mathrm{~d}$ old chick that was knocked from the nest and died. This was the only chick mortality observed during the study, and the only time we equipped a bird with a chick this young.

\section{Prey exploitation}

Following a centennially significant cold water perturbation in 1991 (Drinkwater 1996), large warm water pelagic fishes and squid did not migrate into the region and the dietary diversity of northern gannets decreased markedly (Montevecchi \& Myers 1995). During 1998 to 2002, the gannets preyed mostly on cape- 
lin, which are among the smallest prey that they exploit, often carrying $\geq 20$ in a single load. Most capelin were spent females and males, with very few gravid females. Male capelin are larger than females, but gravid females have the highest energy density (Montevecchi \& Piatt 1984) and are the preferred prey of common murres Uria aalge (Davoren \& Montevecchi 2003). The large multi-prey loading gannets do not discriminate among these small forage fish. Rather, the gannets' landings probably reflect capelin availability (determined by temperature-dependent spawning times) within the constraints of their maximum $20 \mathrm{~m}$ dive depths and $200 \mathrm{~km}$ foraging ranges.

When capelin stocks decreased, gannets landed substantial numbers of Atlantic salmon and other large pelagic fishes. Salmon were a minor prey in the gannets' diets during the 1970s and 1980s, but increased significantly after an anomalous cold water perturbation in 1991 (Montevecchi et al. 2002, Montevecchi \& Cairns 2003, Montevecchi 2007). Due to shifting pelagic food webs during the 1990s, the gannets' prey options were fewer and their diet breadth narrowed.

\section{Foraging tactics and foraging sites}

Large seabird colonies occur in proximity to robust predictable prey fields, giving individuals opportunities to learn about productive foraging sites and to use memory-based foraging strategies (Hamer et al. 2001, Davoren et al. 2003b). Northern gannets from the large offshore Funk Island colony foraged consistently inshore when persistent shoals of capelin provided the bulk of their prey. Common murres from Funk Island and other large predators also forage consistently on these persistent inshore shoals of capelin, i.e. hotspots (Davoren et al. 2003a). During 2002, when these shoals were reduced in abundance and dispersed, more gannets foraged opportunistically offshore from the colony and exploited post-smolt Atlantic salmon.

Individual gannets showed consistency in successive foraging trips, returning to areas where they were recently successful (Benvenuti et al. 1998, Irons 1998, Hamer et al. 2001, Watanuki et al. 2003). Fidelity to feeding areas on successive foraging trips is indicative of memory-based foraging tactics. In the longterm such tactics could facilitate the development of behavioural 'traditions' or hinterlands as has been demonstrated in other studies of seabird foraging ecology (Furness \& Birkhead 1984, Cairns 1989, Grémillet et al. 2004, Garthe et al. 2007a).

Generally, the gannets used a mixed foraging strategy that involved a general fidelity to inshore areas and some wider offshore foraging when capelin were less available and when post-smolt Atlantic salmon moved through the area. Flocks returning from inshore sites were significantly larger than those from offshore, suggesting that it might also have been easier for northern gannets to exploit information (local enhancement) from conspecifics foraging inshore on concentrated shoals of capelin (Wittenberger \& Hunt 1985, Flemming \& Greene 1990). Larger inshore flocks are probably related to the high numbers of gannets foraging there, giving greater opportunity to return to the colony in linear aggregations thereby gaining aerodynamic and energetic benefits. As with other opportunistic generalists (Watanuki et al. 2004), the gannets integrated a mixed array of flexible and repetitive tactics to engage changes in prey availability driven by dynamic oceanographic conditions.

\section{Foraging trip patterning}

Northern gannets flew at sea for about half of their daylight time and stayed on the water at night (see also Hamer et al. 2001, Garthe et al. 2003). The longer birds were at sea, the more they flew and the farther they traveled. Gannets tended to make relatively long initial and final flights from and to the colony in the order of 50 to $60 \mathrm{~km}$. Outbound flights were interrupted more by time on the water than were return flights. Following more intense diving bouts, gannets spent more time on the water, probably for purposes of digestion, resting and self-maintenance (Diamond et al. 1986); very long pauses probably follow self-feeding bouts and shorter ones followed by direct returns to the colony are indicative of chick-provisioning activity (see also Ropert-Coudert et al. 2004).

Prey depletion (Birt et al. 1987) and conspecific interference hypotheses (Hunt et al. 1986, Lewis et al. 2001) predict longer foraging ranges at large colonies. Maximum foraging distances of birds carrying compass loggers ranged between tens and hundreds of kilometres with ranges that extended up to $262 \mathrm{~km}$ (Garthe et al. 2007a.). These ranges are similar to those of gannets nesting in Shetland, UK (Garthe et al. 1999), but shorter than those at larger colonies in the North Sea (Hamer et al. 2000, Lewis et al. 2001) and Gulf of St. Lawrence (Garthe et al. 2007a). Substantial interannual changes in foraging ranges from a single colony are also associated with major shifts in prey bases (Garthe \& Montevecchi 2007).

\section{Coping with changing prey conditions}

Northern gannets use flexible tactics to cope effectively with changes in prey availability and diversity over seasonal, annual and decadal scales. In the north- 
west Atlantic Ocean, the prey landings of gannets shifted from a predominance of large migratory warm water pelagic fishes and squid during the 1970s and 1980 s, to what appears to be a 'default' diet of primarily small forage fish (capelin) through to 2004 (Montevecchi 2007). Yet this major alteration in feeding ecology and diet has had no negative influence on the gannets' breeding populations that have grown considerably during these decades (Chardine 2000, J. W. Chardine pers. comm.).

Under reduced availability of capelin (biomass, number of shoals) in 2002, gannets responded by foraging farther offshore. This is evidenced by foraging locations and lower densities and total numbers of gannets observed during the inshore vessel survey. Gannets caught more large pelagic fishes, which increased their dietary diversity during 2002. The single gannet equipped with a compass logger that foraged offshore in 2002 exhibited the greatest effort of any bird in our study, i.e. highest percentage of time flying (63\%) and most dives during a foraging trip (66\% higher than the next highest effort). The northern gannets' ability to alter their foraging strategies (e.g. foraging location, prey type) under varying conditions (see also Watanuki et al. 2004) is essential for their success in a dynamic pelagic environment.

Acknowledgements. We thank J. Heath, A. Hedd, J. Russell and I. Stenhouse for heroic assistance in the field. We are grateful to Captain L. Easton and family for crewing our expeditions and surveys. We thank C. Burke for help with figure preparation and 4 anonymous reviewers who provided very helpful and constructive comments for manuscript improvement. This research involves international collaboration and was supported by Natural Sciences and Engineering Research Council of Canada (NSERC: Discovery and Shiptime grants and a Post-Doctoral Fellowship) and a subvention from Fisheries and Oceans Canada to W.A.M. and G.K.D., the Italian Centre for National Research (to S.B.) and from the German Research Foundation (DFG Ga 617/1 to S.G.) and the Research and Technology Centre (FTZ).

\section{LITERATURE CITED}

Benvenuti S, Bonadonna F, Dall'Antonia L, Gudmundsson GA (1998) Foraging flights of breeding thick-billed murres (Uria lomvia) as revealed by bird borne direction recorders. Auk 115:57-66

Benvenuti S, Dall'Antonia L, Lyngs P (2001) Foraging behaviour and time allocation of chick-rearing Razorbills, Alca torda, at Græsholmen, central Baltic Sea. Ibis 143:402-412

Birt VL, Birt T, Goulet D, Cairns DK, Montevecchi WA (1987) Ashmole's halo: direct evidence for prey depletion by a seabird. Mar Ecol Prog Ser 40:205-208

Bowen WD, Beck CA, Iverson SJ, Austin D, McMillan JI (2006) Linking predator foraging and diet with variability in continental shelf ecosystems: grey seals of eastern Canada. In: Boyd IL, Wanless S, Camphuysen CJ (eds) Top predators in marine ecosystems: their role in monitor- ing and management. Cambridge University Press, Cambridge, $\mathrm{p}$ 63-81

Bunce A (2000) Population dynamics of Australasian gannets Morus serrator breeding in Port Phillip Bay, Victoria: competition with fisheries and the potential use of seabirds in mapping marine resources. PhD thesis, University of Melbourne

Burger AE, Cooper J (1984) The effects of fisheries on seabirds in South Africa and Namibia. In: Nettleship DN, Sanger GA, Springer PF (eds) Marine birds: their feeding ecology and commercial fisheries relationships. Canadian Wildlife Service, Ottawa, p 150-160

Cairns DK (1989) The regulation of seabird colony size: a hinterland model. Am Nat 134:141-146

Chardine JW (2000) Census of northern gannet colonies in the Atlantic Region in 1999. Can Wildl Serv Tech Rep Ser No 361

Croxall JP (ed) (1987) Seabirds: feeding ecology and role in marine ecosystems. Cambridge University Press, Cambridge

Dall'Antonia P, Dall'Antonia L, Ribolini A (1993) Flight path reconstruction of birds by a route recorder. In: Mancini $\mathrm{P}$, Fioretti S, Cristalli C, Bedini R (eds) Biotelemetry XII. Proc XII Int Symp Biotelemetry. Litographica Felici, Pisa, p 544-549

Davoren GK, Burger AE (1999) Differences in prey selection and behaviour during self-feeding and chick provisioning in rhinoceros auklets. Anim Behav 58:853-863

> Davoren GK, Montevecchi WA (2003) Signals from seabirds indicate changing biology of capelin stocks. Mar Ecol Prog Ser 258:253-261

> Davoren GK, Montevecchi WA, Anderson JT (2003a) Distributional patterns of a marine bird and its prey: habitat selection based on prey and conspecific behaviour. Mar Ecol Prog Ser 256:229-242

> Davoren GK, Montevecchi WA, Anderson JT (2003b) Search strategies of a pursuit-diving marine bird and the persistence of prey patches. Ecol Monogr 73:463-481

> Davoren GK, Anderson JT, Montevecchi WA (2006) Shoal behaviour and maturity relations of spawning capelin (Mallotus villosus) off Newfoundland: demersal spawning and diel vertical movement patterns. Can J Fish Aquat Sci 63:268-284

Diamond JM, Karasov WH, Phan D, Carpenter FL (1986) Digestive physiology as a determinant of foraging bout frequency in hummingbirds. Nature 320:62-63

> Drinkwater KF (1996) Atmospheric and oceanographic variability in the northwest Atlantic during the 1980s and early 1990s. J Northwest Atl Fish Sci 18:77-97

> Falk K, Dall'Antonia L, Benvenutti S (2001) Mapping pre- and post-fledging foraging locations of thick-billed murres in the North Water polynya. Ecography 24:625-631

Flemming SP, Greene E (1990) Making sense of information. Nature 348:291-292

> Furness RW, Birkhead TR (1984) Seabird colony distributions suggest competition for food supplies during the breeding season. Nature 311:655-656

Garthe S, Montevecchi WA (2007) Foraging tactics of northern gannets: flexibility, changing environments and opportunistic predation. Pacific Seabird Group Meeting, Asilomar, CA

- Garthe S, Camphuysen CJ, Furness RW (1996) Amounts of discards by commercial fishes and their significance as food for seabirds in the North Sea. Mar Ecol Prog Ser 136: $1-11$

> Garthe S, Grémillet D, Furness RW (1999) At-sea-activity and foraging efficiency in chick-rearing northern gannets Sula 
bassana: a case study in Shetland. Mar Ecol Prog Ser 185: 93-99

Garthe S, Benvenuti S, Montevecchi WA (2000) Pursuitplunging by gannets (Sula bassana) feeding on capelin (Mallotus villosus). Proc R Soc Lond B Biol Sci 267: $1717-1722$

- Garthe S, Benvenuti S, Montevecchi WA (2003) Temporal patterns of foraging activities of northern gannets Sula bassana in the north-west Atlantic. Can J Zool 81:453-461

Garthe S, Montevecchi WA, Chapdelaine G, Rail JF, Hedd A (2007a) Contrasting foraging tactics by northern gannets in different oceanographic domains with different prey fields. Mar Biol 151:687-694

Garthe S, Montevecchi WA, Davoren GK (2007b) Flight destinations and foraging behavior of northern gannets preying on a small forage fish in a Low Arctic ecosystem. Deep-Sea Res II 54:311-320

Grémillet D, Dell'Omo G, Ryan PG, Peters G, Ropert-Coudert Y, Weeks SJ (2004) Offshore diplomacy, or how seabirds mitigate intra-specific competition: a case study based on GPS tracking of cape gannets from neighbouring colonies. Mar Ecol Prog Ser 268:265-279

- Hamer KC, Phillips RA, Wanless S, Harris MP (2000) Foraging ranges, diets and feeding locations of gannets Sula bassana in the North Sea. Mar Ecol Prog Ser 200:257-264

Hamer KC, Phillips RA, Hill JK, Wanless S, Wood AG (2001) Contrasting foraging strategies of gannets Sula bassana at two North Atlantic colonies: foraging trip duration and foraging area fidelity. Mar Ecol Prog Ser 224:283-290

Hunt GL, Eppley ZA, Schneider DC (1986) Reproductive performance of seabirds: the importance of population and colony size. Auk 103:306-317

Irons DB (1998) Foraging area fidelity of individual seabirds in relation to tidal cycles and flock feeding. Ecology 79: $647-655$

Lewis S, Sherratt TN, Hamer KC, Wanless S (2001) Evidence of intraspecific competition for food in a pelagic seabird. Nature 412:816-819

> Montevecchi WA (2007) Binary responses of northern gannets (Sula bassana) to changing food web and oceanographic conditions. Mar Ecol Prog Ser 352:213-220

Montevecchi WA, Berruti A (1991) Avian bioindication of pelagic fishery conditions in the southeast and northeast Atlantic. Int Ornithol Congr 20:2246-2256

Montevecchi WA, Cairns DK (2003) Predation by gannets on post-smolt Atlantic salmon: research implications and research opportunities. In: Mills DH (ed) Salmon on the edge. Blackwell Science, Oxford, p 61-77

Montevecchi WA, Myers RA (1995) Prey harvests of seabirds reflect pelagic fish and squid abundance on multiple spatial and temporal scales. Mar Ecol Prog Ser 117:1-9

Montevecchi WA, Piatt JF (1984) Composition and energy contents of mature inshore spawning capelin (Mallotus villosus): implications for seabird predators. Comp Biochem Physiol A Comp Physiol 78:15-20

Montevecchi WA, Tuck LM (1987) Newfoundland birds:

Editorial responsibility: John Piatt,

Anchorage, Alaska, USA exploitation, study, conservation. Nuttall Ornithological Club, Cambridge

Montevecchi WA, Ricklefs RE, Kirkham IR, Gabaldon D (1984) Growth energetics of nestling northern gannets, Sula bassanus. Auk 101:334-341

- Montevecchi WA, Cairns DK, Myers RA (2002) Predation on marine-phase Atlantic salmon (Salmo salar) by gannets in the northwest Atlantic. Can J Fish Aquat Sci 59:602-612

Nelson B (1980) The Atlantic gannet. Buteo Books, Vermillion, $\mathrm{SD}$

Ollason JG, Yearsley JM, Liu K, Ren N (2006) Modelling the behaviour of individuals and groups of animals foraging in heterogeneous environments. In: Boyd IL, Wanless S, Camphuysen CJ (eds) Top predators in marine ecosystems: their role in monitoring and management. Cambridge University Press, Cambridge, p 294-309

Orians GH, Pearson NE (1979) On the theory of central place foraging. In: Horn DJ, Mitchell RD, Stairs GR (eds) Analyses of ecological systems. Ohio State University Press, Columbus, OH, p 154-177

- Pennycuick C (1997) Actual and 'optimum' flight speeds: field data reassessed. J Exp Biol 200:2355-2361

Piatt JF (1990) The aggregative response of common murres and Atlantic puffins to schools of capelin. Stud Avian Biol 14:36-51

Ropert-Coudert Y, Grémillet D, Ryan P, Kato A, Naito Y, Le Maho Y (2004) Between air and water: the plunge dive of the Cape Gannet Morus capensis. Ibis 146:281-290

Siegel S (1957) Nonparametric statistics. McGraw-Hill, New York

Tasker ML, Hope Jones P, Dixon T, Blake BF (1984) Counting seabirds at sea from ships: a review of methods employed and a suggestion for a standardized approach. Auk 101: 567-577

Watanuki Y, Takahashi A, Sato K (2003) Feeding area specialization of chick-rearing Adélie penguins Pygoscelis adeliae in a fast sea ice area. Ibis 145:558-564

> Watanuki Y, Ishikawa K, Takahashi A, Kato A (2004) Foraging behavior of a generalist marine top predator, Japanese cormorants (Phalacrocorax filamentosus), in years of demersal versus epipelagic prey. Mar Biol 145:427-434

Watanuki Y, Daunt F, Takahashi A, Newell M, Wanless S, Sato K, Miyazaki N (2008) Microhabitat use and prey capture of a bottom-feeding top-predator, the European shag, shown by camera loggers. Mar Ecol Prog Ser 356: 283-293

Weimerskirch H, Chastel O, Ackerman L, Chaurand T, Cuenot-Chaillet F, Hindermeyer X, Judas J (1994) Alternate long and short foraging trips in pelagic seabird parents. Anim Behav 47:472-476

Wilson P, Weimerskirch H, Lys P (1995) A device for measuring seabird activity at sea. J Avian Biol 26:172-175

Wittenberger JF, Hunt GL (1985) The adaptive significance of coloniality in birds. In: Farner DS, King JR, Parkes KC (eds) Avian biology, Vol 8. Academic Press, San Diego, CA, p 1-77

Submitted: August 20, 2008; Accepted: March 12, 2009 Proofs received from author(s): June 9, 2009 